Fullagar, S., \& Pavlidis, A. (2020). Thinking through the Disruptive Effects and Affects of the Coronavirus with Feminist New Materialism. Leisure Sciences, 1-8.

https://doi.org/10.1080/01490400.2020.1773996

(This pre-print author version may differ slightly from the published article)

\begin{abstract}
The disruptive biocultural force of the coronavirus highlights the value of more-than-human perspectives for examining the gendered effects and affects on our everyday lives and leisure practices. Pursuing this line of thought our article draws upon the insights of feminist new materialism as intellectual resource for considering what the coronavirus "does" as a gendered phenomenon. We turn to this body of feminist scholarship as it enables us to attune to what is happening, what remains unspoken and to pay attention to "the little things" that may be lost in a big crisis. Writing through the complexity of embodied affects (fear, loss, hope), we focus on the challenge to humanist notions of "agency" posed by these shifting timespace relations of home confinement, restricted movement and altered work-leisure routines. We explore the tensions arising from "home" as an historical site of gendered inequality and a new site of enhanced capacity.
\end{abstract}

Keywords: Affect, feminism, gender, more-than-human, women's leisure

\title{
Thinking through the disruptive effects and affects of the coronavirus with feminist new materialism
}

\section{A place of confining freedom}

Taking a shower

first cold, then warm, then too damn hot

but I like it that way, just bearable.

Shrinking, making smaller, contained in that hot, wet cubicle

this containment the only moment of freedom in this tough day.

As people die and mothers struggle 
people of Asian descent are on the receiving end of hateful, violent attacks.

My own children struggle to fall asleep, his small heart aches

from a panic attack brought on by this wildfire.

Extinguished for a moment by the hot water,

the steaming room and a minute alone.

Time alone, the water washes over me

for a moment there is nothing else but the heat, the wet

my own body being washed clean.

Thoughts intrude; make-shift morgues, children in poverty,

women scared in their own homes

Little pockets and small leisure moments created

so we don't feel 'shut down',

imprisoned

not quite in prison, but confined.

The future murmurs, moving us ever so slightly.

(AP)

COVID-19 presses against our thinking, highlighting the value of leisure practices in supporting survival and flourishing as both individual and collective concerns. Loss, death, and trauma have intensified the affective relations and gendered inequities of "home" as a particular leisure site a timespace of confinement and freedom. Our opening poem offers a creative analytic (Parry \& Johnson, 2007) murmuring, inspired by Deleuze and Guattari's "sound of a contagious future, the murmur (rumeur) of new assemblages of desire, of machines, and of statements, that insert themselves into the old assemblages and break with them" (1986, p. 83). Leisure worlds have become saturated with the affective intensities of a relentless corona news cycle that permeate and disrupt living rooms and digital devices. Words and images of sickness and graphs of 
infection rates do not simply "represent" the external world, they are produced through an affective economy (Ahmed, 2004) that circulates fear, anger, loss, and frustration with political (in)action.

These dynamic affects and sleepless nights have moved us to write this commentary to think our way through with the intellectual resources of feminist new materialism (Barad, 2007; Coole \& Frost, 2010; Fullagar, 2017; Haraway, 2016; Kumm et al., 2018; Lupton, 2019; Thorpe et al., 2019). It is an analytic approach that orients us towards the "moments of affirmation and moments of dissonance" afforded by changing leisure practices, policies and provision - in the effort to counter sexism, racism, poverty, homophobia, transphobia and environmental degradation (Bargetz, 2019, p.193). However, these disturbing affects are also countered by connectedness, belonging and hopefulness that emanate from an array of creative social media moments via 'home' as a private-public and gendered leisure site; music, dance, yoga, cooking, art, fitness practices and shared humour reassert their embodied value (Fullagar et al., 2018b). Arbitrary divisions between private and public, home and work, digital and physical, human and nonhuman, self and other, are collapsing and reconfiguring leisure in lockdown through a radically different timespacemattering (Barad, 2007).

\section{Gendered leisure in materialising worlds}

We need different ways of conceptualising leisure beyond individualised models of 'human agency', to enable a deeper grasp of the embodied, affective relations that produce leisure phenomena as an assemblage of gendered forces (Braidotti, 2013; Fullagar et al., 2019). Feminist new materialism offers a relational approach to leisure that is attuned to ambivalence and the 
multiplicity of meaning; the gendered experience of despair and trauma enacted in highly normalised ways, alongside the "performative tactic[s] of counter-feelings...countermanifestation" (Bargetz, 2019, p. 193). This is a multiscalar endeavour. It's the little things, and the big things at once. And everything in-between. The tiny pleasures of hot showers, hugs from a toddler or dog, your favourite comedy show, growing or making things, a walk in the park, or a good cry with a friend. To borrow from Barad (2007) we suggest that such affective practices are about "making worlds...materially engaging as part of the world in giving it specific material form" (p. 91). Feminist materialisms have us thinking about disrupting this disruption.

As a disruptive knowledge practice feminist theory seeks multiplicity while undoing the binary thinking that continues to marginalise and "fix in place" material and discursive forces (including policies, practices, ideologies and affects). The pandemic evokes these tensions for us to think with - how does COVID-19 come to matter in gendered ways and for different women (recognizing cis, trans and fluid gender identifications, intersectionality and more-than-human worlds)? How does leisure scholarship grapple with the affects of loss and joy, as well as the limitations of humanist assumptions about agency? Today we face COVID-19, yet the a/effects of global warming and inequality related climate crises loom large in our planetary future.

\section{Gendered risk and entangled agency}

Governments have been largely silent about the gendered effects of the virus (Gaweda, 2020), while activists and women's organizations, such as UN Women, have called for feminist perspectives to examine the impacts of the pandemic and governmental responses on gender inequalities (Stephenson \& Harris-Rimmer, 2020). A recent survey by the Australian Bureau of 
Statistics found that women were statistically more likely than men to be experiencing anxiety and/or depression in the mid-March to mid-April time period (ABS, 2020). Statistics from the United States show that younger women (20 to 29) and African Americans are experiencing higher rates of infection (Statista, 2020), potentially due to their role in front line services. The conditions of everyday freedom are not only gendered, they are also shaped by intersectional forces - the entanglements of class, race, sexuality, age, illness/disability (Hinton, et al., 2015). Within such entanglements, Barad (2007, p. 32) poses a key feminist question that shifts from what gender differences exist to "how differences get made, what gets excluded and how these exclusions matter" with respect to gender justice.

Across the globe feminized labor holds up the essential work of the health, care, food provision and education sectors. Many women have lost their casualized jobs, feminized poverty increases housing and food pressures. Women of colour are subject to racial abuse and structural racism, while an increasing number are experiencing the horror of gender-based violence or 'domestic terrorism' in the homes they are confined to (Gearing, 2020). The defensive borders created around the ownership of homes, bodies, nature, countries, territories - have fuelled racism, sexism and exploitation for profit and patriarchal pleasure. As (eco)feminist, Indigenous and scholars of colour have argued the human experience of vulnerability, uncertainty and precarious living, is profoundly biopolitical. Precarity exacerbated by the crisis is bound up with an ontological politics premised upon the othering of difference (nature-culture, self-other, mindbody, etc)(Barad, 2007; Butler, 2004; Gilson, 2014; Haraway, 2016; Nxumalo, 2020). Watene (2020) noted New Zealand's effective response to the crisis (led by Prime Minister Jacinda Ardern as one of several effective women leaders in the crisis) invoked "the well-known Māori 
phrase He waka eke noa (we are all in this together)" and yet there exist inequities in social life and higher rates of infection for Māori people.

Dominant masculine fantasies of mastery 'over' others (nature, the body, death, other bodies...) are embodied by male leaders such as US President Trump and Brazilian President Bolsonaro, who recently responded with "so what?" to questions about Brazil's rising death toll (Phillips, 2020). Yet, humans are nature; living microbiomes that host and transmit a diverse range of helpful and harmful microorganisms and non-living agents, such as viruses. COVID-19 is thought to have emerged from human-animal transmission through the consumption of infected wildlife; animals that are increasingly threatened by profit motives. An invisible non-living agent becomes alive in bodies and halts the flow of capital, people and commodities, causing global supply chains to faulter. The fantasy of masculine privilege has failed, revealing a profound vulnerability with higher death rates for men. This death rate is largely framed through biological theories, suggesting that the lower risk for females is related to "traits that enhance their ability to care for young, hence their stronger immune system" (Graves, 2020). These kinds of explanations ignore the biocultural question of how transmission is mediated through the micropolitics of space. Masculine body comportment has been shown to claim more entitlement to space (Young, 1980). While thousands were dying in Italy and China during March, crowds of mainly men gathered to attend the Melbourne Grand Prix. Even Australia's Prime Minister announced in self-assured fashion that he would be "going to the footy" (Speers, 2020). Public pressure from varying groups shut down the Grand Prix and the football at the $11^{\text {th }}$ hour: with its large crowds men's sport became identified by public health experts a key vector of disease. 


\section{Rethinking leisure through relational capacities}

Turning to feminist new materialism, the question of change (and leisure choice) is conceived of as complexity and emergence. Attention is focussed on multiple affects and (digitally mediated) interrelationships that produce expanded or limited agentic capacities, rather than atomistic agents (Barad, 2007; Fullagar et al., 2018a). Rational choice models (Simpson \& Harrell, 2007) have long assumed a static notion of the self and world as separate entities where leisure practices appear to be chosen and enacted through sheer will. The ontological assumptions of such theories fail to grasp complexity and in the current context the radical revision of "home" as an intense site of practically everything. Thinking beyond the atomistic individual we argue that it is through the human and nonhuman, global and local relations that leisure practices are assembled, producing particular affects and meanings in historically specific ways (that plug into related formations involving un/paid work, care, community, consumption etc) (Deleuze, 1986). Leisure is a multi-scalar phenomenon and not simply constituted in terms of the macro or micro. From this perspective relational power is understood to work through different scales connecting global flows with the micropolitics of gendered patterns in everyday life. Importantly, agentic capacities are not conceptualized as residing 'within' individual humans but rather are distributed relationally. The generative force of human and nonhuman 'matter' is recognized as an emergent and gendered relation instead of an inherent property or source of agency (Coole \& Frost, 2010).

Nowhere has this been clearer than in this current pandemic and the distributed agency at play.

Governments and leaders around the world have institutionalised responses to the invisible threat of COVID-19, via new policies with lock-downs, emergency powers and criminalising seemingly innocuous leisure practices (sitting with another on a park bench for example) (see for 
example, the Queensland Government's Home Confinement, Movement and Gathering Direction from the Chief Health Officer, 2020). This 'state of exception' creates new legal and political parameters of agentic capacity that intersect with the material and affective conditions we find ourselves in at home.

\section{Gendered homes and affective capacities}

Home as a safe place to retreat from contagion is an assumed ideal in many government responses, being for some a privileged location and others a reminder of dispossession, nonbelonging and loss. As an historical site of gendered inequality home is being configured as a new site of enhanced capacity where governments and employers assume a "costless", "largely frictionless" space (and time) for work, leisure, sport, sustenance, care (and childcare), and education (Jenkins, 2020). These shifting boundaries of life alter how we experience home through material and discursive forces, condensing memories, sensory moments and future desires into what Barad (2007) calls timespacemattering. Physical distancing measures and digital communication are transforming the social relations of leisure via new ways of becoming 'together/apart'. As familiar leisure routines disappear, the quickening pulse of anxiety and the painful realization of loss generate different ways of affectively re-organizing everyday life. Such disruptions are not simply gender neutral 'behavioural' changes, they are profoundly political and visceral, affecting how we feel, relate and respond in the context of privatepublic life enacted via digital media. Small homes or apartments impede movement, large homes with the privilege of gardens provide moments of reprieve and time in nature. There are jobs which can be easily done at home, jobs lost or income reduced, high speed internet connection (or not), mental health challenges and more. Home is profoundly entangled with leisure-work-care- 
assemblages that reconfigure choices and gendered relations that press upon us in ways that intensify or relieve anxieties.

Ahmed's (2004) writing on the affective economy of fear resonates strongly with our current situation in which the personal is political. She argues that, "emotions play a crucial role in the 'surfacing' of individual and collective bodies through the way in which emotions circulate between bodies and signs" (Ahmed, 2004, p.117). The home-leisure-work-care-assemblage is a complex multiplicity of emotions, constituted through forces that produce movement and tension. Leisure relations with home are gendered configurations of timespacemattering; experienced as safe (from the virus and contagion) and dangerous (from domestic violence, coercive control); stressful (juggling care of young children with domestic work, paid work, selfcare and more) and comforting (to be close with those you love during this crisis).

These multiple affects shape agentic capacities for different women with respect to their material and discursive conditions. Losing a job, or losing access to work-place routines, communitybased leisure relationships or time spent with or without others can be felt and embodied through a particular kind of dislocatedness or grief (Kalaichandran, 2020). Home confinement thus constitutes self-world relationships anew as immobility is felt through reduced capacity to access leisure sites and sensory connection (cafes only offer takeaway, sports clubs are closed, parks and paths enable movement only for 'exercise' at a distance etc). We are yet to understand the differential impact of collective anxiety arising from living with the constant 'threat' of COVID19 and the loss of agentic capacities in the enactment of leisure lives, or how to respond to the potential trauma as home-world relations shift again. 


\section{Gendered contours of a post-COVID world}

In wealthy settler nations such as Australia, responses to the gendered risks of COVID-19 have played out in both normative and surprising ways. The conservative male dominated government has engaged in an ideological backflip with new funding allocated to provide free childcare, domestic violence prevention, mental health and increased unemployment benefits, as the state is repositioned as an intervening force in a collapsing global market - the effect of an invisible virus that permeates the borders of bodies and nation states. Yet this support and social infrastructure, has been set to "snap back". Australia's current Prime Minister, Scott Morrison has been clear that the $\$ 200$ billion or more of special funding will be turned off and life returned to "prepandemic normality" post-COVID-19 (Farr, 2020). Yet any return to business as usual is an impossible fantasy, as Barad (2014, p. 9) suggests, a feminist return is a process of renewal, "returning - not by returning as in reflecting or going back to a past that was, but re-turning as in turning it over and over again". Notions of "snapping back" or a return to "normal" fail to grasp how affective relations are transforming gendered experiences, environments and social institutions in the COVID-19 world (Fullagar, 2020). Revitalising leisure lives and services will require a deep appreciation of the affective assemblages that will profoundly shape the gendered contours of public spaces and embodied engagement.

\section{References}

Ahmed, S. (2004). Affective economies. Social text, 22(2), 117-139.

Australian Bureau of Statistics (2020). 4940.0 - Household Impacts of COVID-19 Survey, 14-17 Apr 2020, [webpage] https://www.abs.gov.au/ausstats/abs@.nsf/Latestproducts/4940.0Main\%20Features114$17 \% 20 \mathrm{Apr} \% 202020$ ?opendocument\&tabname $=$ Summary \&prodno $=4940.0 \&$ issue $=14$ $17 \% 20 \mathrm{Apr} \% 202020 \&$ num $=\&$ view $=$ 
Bargetz, B. (2019). Longing for agency: New materialisms' wrestling with despair. European Journal of Women's Studies, 26(2), 181-194.

Barad, K. (2007). Meeting the universe halfway: Quantum physics and the entanglement of matter and meaning. Durham, NC: Duke University Press.

Barad, K. (2014). Diffracting Diffraction: Cutting Together-Apart. Parallax, 20(3), 168-187.

Butler, J. (2004). Precarious life: The powers of mourning and violence. New York: Routledge.

Coole, D., \& Frost, S. (Eds.) (2010). New materialisms. Durham, NC: Duke University Press.

Deleuze, G. (1986). Kafka: Toward a minor literature (Vol. 30). Minneapolis: University of Minnesota Press.

Fullagar, S. (2020). Recovery and regeneration in community sport: What can we learn from pausing play in a pandemic? 6 May, The Machinery of Government, Griffith Policy Innovation hub, https://medium.com/the-machinery-of-government/recovery-andregeneration-in-community-sport-9a217bd70aef

Fullagar, S., O’Brien, W., \& Pavlidis, A. (2019). Feminism and a vital politics of depression and recovery. Champ: Springer.

Fullagar, S. (2017). Post-qualitative inquiry and the new materialist turn: Implications for sport, health and physical culture research. Qualitative Research in Sport, Exercise and Health, 9(2), 247-257.

Fullagar, S., Parry, D. \& Johnson, C. (2018a) Digital dilemmas through networked assemblages: Reshaping the gendered contours of our future. In D. Parry, C. Johnson \& S. Fullagar. (Eds.), Digital dilemmas: Transforming gender identities and power relations in everyday life. London: Palgrave Macmillan. pp. 225-244.

Fullagar, S, Pavlidis, A \& Francombe-Webb, J. (2018b). Feminist theories after the poststructuralist turn. In Parry, D. (Ed). Feminisms in Leisure Studies: Advancing a Fourth Wave, New York: Routledge. pp.34-57.

Farr, M. (2020). Morrison reminds us nothing lasts forever - especially the coronavirus spending spree. The Guardian Australia [online article], accessed April $22^{\text {nd }} 2020$ from https://www.theguardian.com/australia-news/2020/apr/02/morrison-insists-nothing-lastsforever-especially-the-coronavirus-spending-spree

Gaweda (2020). The politics of the missing gender perspective: Responding to the Coronavirus pandemic through parliamentary politics. EUGENDE Gender, party politics and democracy in Europe: A study of European Parliament's party groups, Tampere University [online article]. April $17^{\text {th }}$ accessed 22 April from https://research.uta.fi/eugendem/the-politics-of-the-missing-gender-perspectiveresponding-to-the-coronavirus-pandemic-through-parliamentary-politics/ 
Gearing, A. (2020). Coronavirus and 'domestic terrorism': How to stop family violence under lockdown, The Conversation, April 1, https://theconversation.com/coronavirusand-domestic-terrorism-how-to-stop-family-violence-under-lockdown-135056

Gilson, E (2014). The ethics of vulnerability: A feminist analysis of social life and practice, Routledge: New York.

Graves, J. (2020). Coronavirus kills up to twice as many men as women and the reason is in our genes. The Conversation. April 20 ${ }^{\text {th }}$, Accessed April $22^{\text {nd }} 2020$ from https://heconversation.com/why-do-more-men-die-from-coronavirus-than-women136038

Haraway, D. (2016). Staying with the trouble: Making kin in the Chthulucene. Durham, NC: Duke University Press.

Hinton, P., Mehrabi, T., \& Barla, J. (2015). New Materialisms_New colonialisms (New Materialism. Networking European Scholarship on 'How Matter Comes to Matter', New Materialisms on the Crossroads of the Natural and Human Sciences, position paper). https://doi.org/10.1215/9780822392996

Jenkins, F. (2020). Did our employers just requisition our homes? The Canberra Times, April 4. https://www.canberratimes.com.au/story/6701054/did-our-employers-just-requisitionour-homes/

Kalaichandran, A (2020). We're not ready for this kind of grief: The coronavirus pandemic will leave lasting emotional scars. The Atlantic, April 13, https://www.theatlantic.com/ideas/archive/2020/04/were-not-ready-for-this-kind-ofgrief/609856/

Kumm, B. E., Berbary, L. A., \& Grimwood, B. S. (2019). For those to come: An introduction to why posthumanism matters. Leisure Sciences, 41(5), 341-347.

Lupton, D. (2019). 'Things that matter': Poetic inquiry and more-than-human health literacy. Qualitative Research in Sport, Exercise and Health, 1-16. https://doi.org/https://doi.org/10.1080/2159676X.2019.1690564

Nxumalo, F. (2020). Situating Indigenous and Black Childhoods in the Anthropocene. In A. Cutter-Mackenzie-Knowles, K. Malone, \& E. Barratt Hacking (Eds.), Research Handbook on Childhoodnature: Assemblages of Childhood and Nature Research (pp. 535-556). Cham: Springer.

Parry, D. C., \& Johnson, C. W. (2007). Contextualizing leisure research to encompass complexity in lived leisure experience: The need for creative analytic practice. Leisure sciences, 29(2), 119-130.

Queensland Health, (2020). Home Confinement, Movement and Gathering Direction, [legislation], effective $2^{\text {nd }}$ April 2020, accessed $21^{\text {st }}$ April 2020 from https://www.health.qld.gov.au/system-governance/legislation/cho-public-health- 
directions-under-expanded-public-health-act-powers/home-confinement-movementgathering-direction

Phillips, T. (2020). "So what?": Bolosonara shrugs off Brazil's rising coronavirus death toll. The Guardian [online article], 29 April 2020, https://www.theguardian.com/world/2020/apr/29/so-what-bolsonaro-shrugs-off-brazilrisingcoronavirusdeathtoll? $\mathrm{CMP}=\mathrm{fb}$ _gu\&utm medium $=$ Social\&utm_source=Facebook\&fbclid $=$ IwAR07kPkayKS3RSygHov5M 5ZvTnieICKa-CzyiWvgIght0ybXCxoCzpU M\#Echobox=1588168827

Simpson, B., \& Harrell, A. (2007). Rational choice theories. The Blackwell encyclopedia of sociology. New Jersey: John Wiley \& Sons.

Speers, D. (2020). Scott Morrison's 'f-word' misread the public mood on the coronavirus pandemic. $A B C$ News [online article] $6 \mathrm{Apr}$, accessed $22^{\text {nd }}$ April 2020 from https://www.abc.net.au/news/2020-03-15/coronavirus-scott-morrison-footy-nextinformation-campaign/12054174

Statista (2020). Number of COVID-19 cases in Australia April 27, 2020, by age and gender, [webpage], https://www.statista.com/statistics/1104012/australia-number-of-coronaviruscases-by-age-group/

Stephenson, E \& Harris-Rimmer, S. (2020). Covid-19 responses: Why feminist leadership matters in a crisis, The Interpreter, March 31. Lowy Institute, https://www.lowyinstitute.org/the-interpreter/covid-19-responses-why-feministleadership-matters-crisis

Thorpe, H., Clark, M., \& Brice, J. (2019). Sportswomen as 'biocultural creatures': Understanding embodied health experiences across sporting cultures. BioSocieties, 1-21. https://doi.org/10.1057/s41292-019-00176-2

Watene, K. (2020). Caring for community to beat coronavirus echoes Indigenous ideas of a good life, The Conversation, April 24. https://theconversation.com/caring-forcommunity-to-beat-coronavirus-echoes-indigenous-ideas-of-a-good-life

Young, I. M. (1980). Throwing like a girl: A phenomenology of feminine body comportment motility and spatiality. Human studies, 3(1), 137-156. 